\title{
4 \\ Uncovering the Main Root Cause: The Mindset Factor
}

\section{The Forgotten 'Mind Over Matter'?}

As we grapple with the question of what went wrong with Africa's development and what the way forward should be, it is no surprise that so many studies have been done on Africa in wide-ranging fields by various experts and organizations. However, in the eyes of the global community at large, Africa is still very much an unknown, yet-to-bediscovered region and hence much academic, scientific and fact-finding research on Africa will follow suit. In business circles, Sub-Saharan Africa is described as 'the last frontier' but the region is already open for the outsiders to take advantage of its potentials.

Africa's development can be an interesting and fascinating subject to ponder on. What makes the field of development most challenging is that, in sum, it is about carrying out the task of bringing about changes where normally the conditions are the least favourable for doing so. Development bears an aspect of international relations and is an inter-disciplinary field, but it is unlike any other, especially from the practitioners' perspective. For example, development cooperation has a fundamentally different working structure compared to other 
areas of engagements or dealings, including conventional diplomacy, public diplomacy, trade and investment, security, the environment, etc. In these fields, countries participate as 'equal entities' and each party focuses on advancing its position from its own end. Whether it is about negotiating or carrying out PR activities, the process is simple and predictable. It is not necessary to worry about the situation of one counterpart or its capacity to play its part; the responsibility that one bears is confined to one's own responsibility.

However, in development cooperation, things are very different and practitioners cannot go about conducting their own business in a matter-of-fact fashion, paying no attention to the situation of others. It is not enough to have shared goals and reach an agreement, and doing well on your part: one has to involve one's counterpart or partner in doing the difficult and necessary things. Development projects are conducted and assessed over the long haul, and for donors, their assignment is not substantively fulfilled until the collaborative work bears fruit in the end. People cannot feel lighthearted when things break down or become white elephants immediately after they have handed over the facilities or programmes to African countries.

Hence, 'rationality' and standard procedures that we are used to following in most fields in international relations do not necessarily apply in development cooperation. If aid projects are to be responsibly carried out in order to produce tangible results, then extra 'human toil' is required, such as a greater level of patience, perseverance and devotion. Frustration and stress levels can become very high when officials in charge in the aid recipient country do not properly respond and follow up.

I think development as a specialized field in its own right has, over time, lost the zeal it needs to have and has settled for the pursuit of human needs and stability. This was driven largely by the unmitigated challenges that the development community has faced in its conventional domain, but current events have also played a part. For instance, what could have been a promising second decade for the world in the new millennium began with an uncertain and troubling international landscape: political destabilization, the eruption of new conflicts, a new 
form of international terrorism, and a refugee crisis impacting Europe and having global ramifications, among others.

We could be overwhelmed by the challenging developments and contingencies around the world, but development initiatives must be focused on the development agenda instead of following the fickle of times. The more the current situation appears to be entangled, the greater need there is to focus on the fundamentals, root causes and 'ultimate solutions'. This is because development is possibly the best answer to most of the ills and problems we face today. As such, it was heartening when, recently, even David Beasley, the Executive Director of the World Food Programme (WFP), said that 'humanitarian dollars should be turned into development dollars'. ${ }^{1}$

We need to have a better misunderstanding of what foreign aid can do. Not all aid is geared towards economic development and, all things considered, the actual portion allotted to economic development is quite small. This is because the spectrum of foreign assistance has expanded over decades to include just about everything, as is reflected by the adoption of universal Sustainable Development Goals (SDGs). The clear phenomenon observable in African development is that the distinction between 'economic development' and 'economic welfare' is increasingly blurred, which I think is a big problem in itself.

To simplify matters, foreign aid can be broken down into four categories: (1) humanitarian assistance; (2) 'social welfare'-type assistance; (3) development assistance; and (4) the promotion of democracy and governance. Humanitarian assistance is for the emergency relief of those suffering as a result of disasters and crises. Social welfare-type programmes target the socially vulnerable or disadvantaged, providing various services to meet their basic needs. While the first two types of assistance are meant to serve the immediate or basic requirements of the recipients, development assistance is for the mid- to long term sustainable development of the recipient nations. These include various types of cooperation like capacity-building, technological cooperation, the construction and handover of facilities and infrastructures, the provision of materials and equipment, the injection of funds, etc. in multiple sectors. Lastly, the promotion of governance, democracy and human rights, and 
regional security are also important areas in which Western donors provide assistance.

Therefore, foreign aid that directly supports economic development in African countries is not particularly apparent. And this is further 'compromised' by how the recipient countries utilize this aid. The problem is that various economic projects often turn out to be short-lived programmes that mainly benefit the officials of counterpart agencies or a limited number of the people concerned. In sum, even these have turned into 'welfare' programmes instead of acting as sustainable means to assist economic development.

Basically, universal economic activities can be considered as either wealth creation or wealth distribution. Wealth creation is about realizing additional production and value that drives economic growth, leading to overall development. Wealth distribution, in policy terms, is the act of 'correcting' market failures from a socio-political standpoint like addressing income inequality and providing public services. If there is no wealth creation, then there is no wealth to distribute. Thus, for Sub-Saharan African countries, the priority should be 'enlarging the pie' through wealth creation, but their general mindset is fixated on the transfer of wealth. Under such circumstances, various assistance programmes are likely to fail. The 'welfare mentality' is so widespread in the region that everyone is looking for solutions to come from somewhere else, while readily blaming outsiders and external factors for their own poverty and troubles. More troubling is the failure or unwillingness to take action, and the deep-seated practice of 'non-implementation' poses the biggest mystery, obstacle and threat to development in Sub-Saharan Africa.

The 'mindset' of people should be brought to the forefront of our attention and considered as a key term in the discourse on Africa's development. If people were to ask what the single most important root cause is of underdevelopment of Sub-Saharan Africa, the best answer I can think of is the 'mindset'. Among the myriad of things that can be considered, the ultimate solution to break the impasse lies in a change of mindset. It is one thing to find reasons for past failures, which is what everybody has been doing, but quite another to make things right in practice, which seldom takes place in the region. 
The 'mindset change approach' beings with it great benefits, in that it is conducive to the 'internalization' of development, enhancing awareness for ownership, and is action-oriented. It brings home what people have forgotten: the plain and simple truth of mind over matter. 'Mindset' can be an elusive term, but it would be useful to confine its meaning to what is relevant to development. Bringing the 'mindset' to the fore in discussion propels search for answers 'from within', which is what development ought to be about in the first place. Too much energy has been spent on secondary and peripheral issues without addressing the core issue of mind over matter.

To make this kind of attitudinal change will not be an easy task, but it is not impossible. It is certainly achievable and there are precedents to prove it. The most prominent example, I would argue, is South Korea. In Africa, Rwanda is seen as an emerging case, following a similar model. Uganda has already adopted this mindset change programme, although it is still in the initial, exploratory phase of doing so. Sub-Saharan African nations should go beyond acquiring knowledge and capacity to espouse mindset change if they are indeed serious about 'radical transformation', and rightly so.

The good news is that in some places in Sub-Saharan Africa, people are beginning to at least be aware and are talking about the mindset issue in an open manner. Uganda is one of those where Korea's experience and know-how in this field has had an influence. Since 2009, the Canaan Farmers School, an institution in South Korea which specializes in mindset change and agriculture programmes, has worked with Uganda. Born out of the destruction of the Second World War and the subsequent Korean War, the Canaan School is reputed to have played an instrumental role in leadership and agriculture training in the early stages of Korea's economic development. The objective of this institution was to eradicate poverty and attain sustainable development through changing the mindsets of rural leaders, who, in turn, would spearhead the change of mindsets in their communities. The School's methodology was adopted later in the model of the New Village Movement (Saemaeul Undong) that became a national campaign in South Korea from 1970. The Saemaul Undong became an icon of a 
successful community-driven, self-help rural development endeavour of Korea that contributed to its overall success in economic development.

\section{The 'Mindset Change' Issue in Sub-Saharan Africa}

Few international experts and observers know that South Korea's economic miracle began with the mindset change campaigns conducted at a national level. When you see various books and articles on Korea's rapid economic growth or 'miracle' written by economists, both Korean and foreign, there is hardly any mention of the mindset change campaigns like the Saemaul Undong. It is only in recent years that the Saemaul Undong was recognized and promoted internationally as a development model, and the Saemaul Undong archives were added to UNESCO's Memory of the World Register in $2013 .^{2}$ In the international development community, UN bodies like the UN Economic Commission for Africa (UNECA) and the United Nations Development Programme (UNDP) are the pioneers in embracing this approach. ${ }^{3}$

There may be many reasons for this, but two things come to mind. One is the tendency or influence of mainstream economics and the other is the fundamental 'political' propensity or bias. First, mainstream economists do not deal with 'extraneous' factors like the people's 'mindset'. What approximates 'mindset' according to scholars is the 'hard work' or 'work ethic' of Koreans. Even Alice Amsden's Asia's Next Giant (1992) does not mention the Saemaul Undong at all. Also, it might be that orthodox economists would have shunned such an 'interventionist' movement.

Another reason why the Saemaul Undong has not received universal praise inside Korea is because of the 'political divide' in the nation. No sooner had Korea achieved rapid economic development, the process of its socio-political evolution, democratization began to unfold. Despite the fact that the Saemaul Undong had a substantial impact on rural development, because it was initiated by the authoritative 
government, the progressive-minded population half-heartedly admitted, or were even critical of, its outcomes. Also, as times have changed and people have become wealthier and more self-centred, they tend to be dismissive of things done in the past and do not enough thought to the situation back then, regarding these things as 'outdated' or 'irrelevant'.

Korea and Sub-Saharan African countries share many similar historical experiences. No sooner had Korea been liberated from Japanese colonial rule in 1945 than it became divided. The subsequent Korean War that started in 1950 devastated the nation. But the great turnaround started with the public programmes to empower the people in the 1950s, and the story of South Korea that unfolded provides valuable lessons for Africa's development.

No one will disagree that without a fundamental change in the mindset of the leaders and the populace, there cannot be real progress. Setting up goals and expressing aspirations is an easy part, but this would be of no avail if they are not followed up with concrete actions. There have been serious misperceptions, negligence or intentional 'looking the other way' on the subject. Development is not a 'stock' but a 'flow' concept in economics, and it is all about change and dynamism, not the maintenance of the status quo. But many in the region seem to mistakenly believe that national wealth can be transferred and stocked up like material goods. But even materials and equipment need proper usage and maintenance in order to be useful. Many facilities built to serve the public, like medical clinics, factories, schools and welfare centres, become useless shortly after they are opened and handed over due to a lack of care and ownership, accompanied by corruption.

Although many factors come into play, the real issue is not the lack of resources or means, but the mindset of the people who are involved and responsible for undertaking the work. Evidently, poor work ethicsthe habit of not thinking ahead and making necessary preparations, not being focused and devoted in relation to one's work, easily quitting one's task, not keeping to deadlines and promise, etc. does so much harm, but this is not mentioned enough. When people imagine poverty in Africa, they tend to think of poverty in terms of lack of means, but one has to think further that poverty can be caused or sustained by the 
failure to manage oneself, like saving money and having plans for making a living and for spending.

In Sub-Saharan Africa, it is customary to see people attributing their problem to outside elements. One East African journalist writes:

[W] hat is it that inhibits our ability to produce our own technologies? Note that most sub-Saharan nations possess political institutions and public policies that (we are told) ensure prosperity. Is it, therefore, our education system which is the problem? Is it our social organization? Is it our colonial history that destroyed our self-belief in our ability to produce our own technologies? Is it the hegemonic ideology of global capitalism that keeps us looking outward for the solutions to our problems? ${ }^{4}$

There are different ways to deal with these needs and problems. People can be introspective, inclined to seek answers and solutions from within, or can have the opposite tendency and put blame on others or expect others to solve their problems. If we had two distinctly different societies, one being 'introspective' and the other having 'disowning' tendencies, which one would fare better? The answer is obvious.

The value of being 'introspective' is that over time, individuals are likely to improve and achieve something because of the 'know thyself' kind of effect that it will have. Skills and technologies can be gained when one strives for them. On the other hand, knowledge and institutions are of no consequence when people are idle and irresponsible. Worse, this 'disowning' tendency breeds a 'don't care' mentality. Because people are not the drivers of their own life, they cannot have high expectations of what can be achieved.

It is baffling as to why people should be reluctant to do the things that will only benefit them, particularly in the longer term. This is not limited to the economic field. Institutions, the rule of law, governance and democracy are only worth anything if they are put into practice. We studied at school that the essence of democracy was deeds and practice. It can be a hollow echo of rhetoric which can degenerate into endless political strife if democracy is not properly understood and embodied by the people. 
Development is about making difficult changes, and admitting and targeting one's own weakness and problems rather than trying to conceal them, so that they can be overcome. Development is what is earned and not what is bestowed by others, and there is no magical formula for it, except that people and the government all have to work conscientiously with a common purpose. In this regard, much more harm is done by being ambiguous, disingenuous, hypocritical and manneristic than being honest, straightforward and practical. Being politically and diplomatically correct all the time may not be a good thing for the sake of development, and straightforwardness could yield better outcomes.

Fortunately, within Africa, people are showing an increasing awareness that the mindset needs to be changed. The call for mindset change has been aired in various regional bodies including the African Union $(\mathrm{AU})$, and it is not uncommon to see African leaders and intellectuals speaking out on this. ${ }^{5}$ Everyone seems to agree that people's mindset should change, but when it comes to how this should be done, people seem to be at a loss and lack clear ideas. This is where we need to break out of the box. Rather than give up or try to avoid the matter, it should be tackled head-on. The ideal scenario would be that the African people themselves take the initiative and make full-fledged efforts in this regard. Development partners can approach this issue with good intentions and without prejudice, being circumspective in relation to the nature of the matter.

Efforts to this end have already been made in Uganda through such projects as the establishment of the National Farmers Leadership Centre (NFLC), which is a training round for mindset change and agricultural development. ${ }^{6}$ Perhaps the best way to break the yoke of the inaction or powerlessness of the people is to 'provoke' them to change. This is because as far as human behaviour is concerned, 'voluntarism' is the surest way forward. The 'mindset change' of the people, if effected, can have far-reaching and 'explosive' repercussions on their lives and society.

There are a number of parallels between Korea's experience and the situation in which Sub-Saharan African countries currently find themselves. One of the areas that Korea identified as crucial for national transformation was the mindset of the people, and the campaign for 
mindset change was essentially about empowering the people. The Korean experience will be examined in Part 4 of this book.

With respect to the substance of the problematic mindset in SubSaharan Africa, I believe that the following can be identified as the syndromes or traits that commonly exist in the region: (1) the dependency syndrome; (2) the 'what's-in-it-for-me' syndrome; (3) the 'backtracking syndrome'; (4) expediency or short-sightedness; (5) a lack of action and implementation; (6) a weak sense of responsibility or ownership; (7) a weak sense of nation or patriotism; and (8) a 'commission culture'?

First, we are all so familiar with the talk of a 'dependency syndrome' in Sub-Saharan Africa that it sounds like a cliché. It is so widespread throughout the region, at all levels in society and the state. For instance, at the provincial level, the general tendency is that the locals wait indefinitely, hoping that the government will come to their aid for the most basic things that they can do for themselves. I had the opportunity to participate in a series of 'community clean-up' exercises in and around Kampala, and on one occasion I was appalled to see first-hand the scene of total negligence and irresponsibility. The site was not a slum by any measure, but apparently the residents were waiting for the city authority workers to show up and remove the rubbish. Even on the very day we were conducting clean-up exercise, many locals, particularly young men, were sitting idly and gazing at us, smiling but declining to take part in the exercise. It was an awful state to witness because this had nothing to do with the people lacking knowledge, capacity or financial resources (the reasons frequently cited for people failing to act), but was a simple matter of willingness. ${ }^{8}$

The 'what's-in-it-for-me?' syndrome is also a widespread phenomenon among the population in the region. This is a tendency to consider one's own interests at all times before anything else. In SubSaharan Africa, it is a well-known fact the poor delivery of public services wrought by civil servants who are devoid of any sense of duty and responsibility is a major hindrance to development. It is a common practice for government officials to engage in personal businesses, and even in their official duties their priority is often misplaced, putting their personal interests over the public interest. There is a tendency to put the official assignments on the back-burner or neglect 
them altogether if they fail to see what is in it for them. Such practice not only breeds conflict of interests and corruption, but also, more fundamentally, drastically undercuts the government's performance. Economic loss due to disruptions and delays in public service, not to mention outright acts of corruption, is said to be enormous.

The 'backtracking syndrome' is the tendency to hold back or back pedal instead of moving forward to build on what has already been achieved. I have always thought of this as a great paradox. It is the problem of failing to 'keep pace', stopping short of meeting the target, and not being consistent and living up to expectations. Where dynamic economic growth is enjoyed, people take it for granted that things improve over time. But this is generally not the case in Africa. There are actually many things that get worse over time, the most noticeable being the deterioration of physical infrastructure and facilities, but it goes well beyond that.

The backtracking syndrome is observable on many fronts and it has huge accumulative or multiple effects at the national level. What is so disheartening is that in many cases, local employees, if they are not placed under the 'special attention' of the management, end up causing problems or missing out on the opportunities that will definitely benefit them (like long-time employment). What we can call the 'self-regulating' or 'self-disciplining' ability of workers is visibly poor. Overall, their will to 'appeal' to their bosses in terms of diligence and performance is short-lived and they do not respond well to the continuing pressures of work. Because Africa's organizations and companies have a weaker management or governance structure compared to foreign entities, their overall organizational output or efficiency is also weaker. In contrast, those who do receive greater recognition in foreign organizations enjoy many benefits and opportunities. They can even be headhunted by higher-paying government organizations and companies. ${ }^{9}$

In any organization, local workers can only benefit if they are attuned to maintaining their level of work because normally, over time, they will gain expertise and productivity in relation to their work. Their pay will increase and it should be a win-win situation for the organization and the employees. But, to our dismay, many show 'regression' instead of steady progress, with the result that they are eventually fired from their 
job. The strange phenomenon is that when rewards and incentives are given to employees, one should expect them to perform more positively, but often the opposite occurs - rather than responding in kind, employees become spoilt, complacent and ask for more. This results in an ironic situation where the good intentions of one party are met by the negative reaction of the other party, which defies logic and rationality.

The next trait is expediency or short-sightedness. This is quite evident in daily work practices. Cutting corners is a tendency of most technicians and workers in the region, meaning that in order to avoid this as much as possible, customers' intervention in terms of continuous on-site 'supervision' is required. This applies to a whole variety of work, ranging from menial chores to construction projects. Sloppy work, the habit of leaving things undone, a failure to keep to deadlines and promises, etc. are the 'norm' rather than the exception. ${ }^{10}$ Generally, there is a lack of attention to detail and thinking ahead, so that even the most basic things to expect like the standardization and linear, geometric correctness of products are not met most of the time.

The lack of implementation or action is another distinctive feature of Sub-Saharan Africa. Ian Clarke, an Irish missionary doctor who became the Mayor of Makindye Division in Kampala, gives a vivid account of such a problem:

Uganda was a great country to live in: the weather was lovely, the vegetation beautiful, and the people friendly and outgoing. Some foreigners came to work in Uganda and were at first enthralled by what they found, particularly by the social life and by how articulate people are, but they often got a rude awakening when it came to the work practices and work ethic. If people could talk their way into making things work, Uganda would have been the best developed country in the world. Donors were impressed with people's grasp of problems and understanding of the steps which should be taken in finding solutions, but then confused as to why so many basic issues on the ground remained unresolved. The problem lay in implementation: many public servants were good at analysing and talking about what should be done, as if the very talking was the same as doing it, but then nothing happened. This lack of implementation of simple things in the public domain was so common that it was accepted as the norm, and one only remarked when anything actually changed. ${ }^{11}$ 
The disinclination to act is a very serious problem under any circumstances. Everybody seems to agree that there has been too much talking and too little action. There is the saying 'easier said than done', but the wise have admonished us against frivolity and talkativeness: 'silence is golden', 'an empty wagon makes more noise', 'action speaks louder than words', 'the superior man acts before he speaks, and afterwards speaks according to his action', etc. ${ }^{12}$

Lack of responsibility and ownership is also a serious obstacle to development. Institutional mechanisms to enforce accountability are important, but what is much more needed is a greater sense of responsibility of the people. The seriousness of the problem is frequently expressed:

It's very hard to get things done, even at the smallest level. But it is very easy to sit and complain about things. Reading social media, one gets the sense that we have increasingly become a complaining nation, not a doing nation. Everywhere complaints abound about our failing healthcare and education system, of corruption and abuse of office. But one hardly reads a story of what those complaining are doing to change the situation. Are we waiting for intervention from God? ${ }^{13}$

What I also see as typical of Sub-Saharan Africa is the practice of offering amnesty in the name of national reconciliation. Political leaders are quick to call for amnesty, thereby promoting impunity. Betrayal and treachery are also common. When I was in West Africa, I saw internal conflicts in many countries where the military as well as political leaders conveniently 'switched sides'. Opportunism prevails, and this leads to a protraction of conflicts because there is no clear will for or path towards its closure. In eastern Africa, South Sudan provides the latest worst-case scenario of what personal greed for power and impunity of leaders can do to a nation.

Weakness in the sense of nation and patriotism is another general trait in the region. The weak sense of nation and patriotism correlates with the weak functioning of states and these two feed off each other. From a national standpoint, the spread of patriotism that transcends tribalism and sectarianism will be an ideal goal to achieve. Many 
African countries suffering from internal strife and disunity ought to realize the fact that this could easily be exploited, engulfing the whole country and the region into a state of crisis.

So how can a sense of nation, national identity, solidarity or patriotism be fostered? The greatest responsibility rests with the political leaders and elites, who should be leading their nation forward by example. But this need not be top-down only-it can work both ways, from topdown and bottom-up, in an interactive fashion with people's voluntarism. Sometimes tragic events can serve as a critical turning point for nations. A good example is the case of Rwanda. What the country has been able to achieve in the aftermath of the genocide is remarkable and has set a high bar for other African countries to match. For an African country, Rwanda has tackled seemingly improbable tasks: good governance, the civic-mindedness of the people, social order and discipline, national solidarity, etc. Most surprising is the cleanliness and orderliness of the capital city Kigali to the extent that it makes one wonder if it is indeed a city in Sub-Saharan Africa. What developing countries desperately need is the government setting an example to 'empower' the people rather than simply trying to curry favour with the people, but without enacting essential reforms.

Lastly, there is a widespread practice of people at all levels wanting to be given 'commission' as if they are entitled to it. Foreign investors are the easy targets and can be hassled by various people, including highlevel government officials, who are hell-bent on rent-seeking. The 'commission culture' is one of the many facets of corruption, but because it stands out so prominently in Sub-Saharan Africa, it can be regarded as a syndrome.

\section{Notes}

1. David Beasley, speaking at 'Geneva Conference on National Transformation-With Special Focus on Science \& Technology, Business \& Industry', 7 October, Africana Hotel, Kampala, Uganda. The conference was jointly organized by the Geneva Institute for 
Leadership \& Public Policy and the Science \& Technology Policy Institute (STEPI) of South Korea.

2. UNESCO, Memory of the World, http://www.unesco.org/new/ en/communication-and-information/memory-of-the-world/register/full-list-of-registered-heritage/registered-heritage-page-1/ archives-of-saemaul-undong-new-community-movement.

3. Internationally, UN development bodies are believed to be the pioneers of recognizing and accepting the Saemaul Undong as a model for rural development. For instance, the United Nations Economic Commission for Africa (ECA) chose the Saemaul Undong as a base model for the Sustainable Modernization of Agriculture and Rural Transformation (SMART), programme in 2008, and the Saemaul Undong was officially introduced to the UNDP in 2015 at the same time as the adoption of the SDGs. Edward Reed, the former country representative of the Asia Foundation to Korea, is a noted international scholar who had studied and written about the Saemaul Undong.

4. Andrew Mwenda, 'Africa Through North Korean Eyes', The Independent, 6 April 2017, https:/www.independent.co.ug/columnists/ andrew-mwenda.

5. For instance, Dr. Nkosazana Diamini-Zuma, the African Union Chairperson, stressed the need for Africans to change their mindsets to achieve development while briefing the Speakers of the African Parliament regarding Agenda 2063 in August 2014. When I came to Uganda in 2011, I noticed that the term 'mindset change' was already a familiar term in government circles perhaps due to Korea's Canaan Farmers School's activities in Uganda.

6. The National Farmers Leadership Centre was formally opened in Uganda in May 2016. This centre, which focuses on mindset change (Saemaul Undong) and agricultural training, is the first of its kind to be created by the Korean government in Sub-Saharan Africa. It is dealt with more in detail in other parts of this book.

7. The observations and propositions made in this book, including the description of typical syndromes in Sub-Saharan Africa, are based on my own experiences in Africa. My personal involvement in development cooperation, including the planning and implementation of development projects in Uganda, provided the inspiration and the empirical grounds for my work. 
8. However, I was very pleased to learn later on that this community did indeed turn itself around and became one of the recognized examples of community environment improvement.

9. Africa's prominent executive bodies that are highly sought-after by white-collar workers also struggle to keep their employees disciplined and in check. So, those who have had a 'good training' and a track record of working in foreign organizations are often preferred by those offices.

10. African countries approach this issue from the viewpoint of 'skilling', but I think this is a fundamental mindset or work ethics problem. The advocates of skilling have the point of correcting identifying the problem as essentially vocational rather than academic in most African countries. But limitations in 'skilling programmes' is that skilling alone cannot address what skilling is purported to achieve; it has to be complemented with work ethics and social ethics.

11. Ian Clarke, How Deep Is This Pothole? (London: Ian Clarke, 2010), p. 195.

12. 'An empty wagon makes more noise' is a Korean proverb and 'the superior man acts before he speaks, and afterwards speaks according to his action' is a saying of Confucius.

13. Andrew Mwenda, The Independent, 20-26 February 2015, p. 9.

Open Access This chapter is licensed under the terms of the Creative Commons Attribution 4.0 International License (http://creativecommons. org/licenses/by/4.0/), which permits use, sharing, adaptation, distribution and reproduction in any medium or format, as long as you give appropriate credit to the original author(s) and the source, provide a link to the Creative Commons license and indicate if changes were made.

The images or other third party material in this chapter are included in the chapter's Creative Commons license, unless indicated otherwise in a credit line to the material. If material is not included in the chapter's Creative Commons license and your intended use is not permitted by statutory regulation or exceeds the permitted use, you will need to obtain permission directly from the copyright holder.

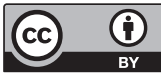

